\title{
The Role of Political Elites in the Development of New Villages in Malaysia
}

\author{
Jeck Seng Wee (Corresponding author) \\ College of Law, Government and International studies, Universiti Utara Malaysia, \\ Malaysia \\ E-mail: weejeckseng@ hotmail.com
}

\begin{abstract}
Siew Nooi Phang (Ph.D)
College of Law, Government and International studies, Universiti Utara Malaysia, Malaysia

E-mail: siewnooi@uum.edu.my
\end{abstract}

Samihah Khalil (Ph.D)

College of Law, Government and International studies, Universiti Utara Malaysia, Malaysia

E-mail: samihah@uum.edu.my

Received: Mar. 13, 2018 Accepted: Apr. 4, 2018 Online published: Apr. 13, 2018

doi:10.5296/jpag.v8i2.13001～URL: https://doi.org/10.5296/jpag.v8i2.13001

\begin{abstract}
Political elites comprise a small group that has power and influence over the "others" in society. Basically, political elites play an important role in the decision-making process of the community. New Villages in Malaysia are influenced by political elites who are the representatives of the village community. These political elites are members of the Malaysian Chinese Association (MCA), a coalition party of the ruling political party. MCA's political elite play an important role in safeguarding the welfare and affairs of the New Village residents. New Villages refer to a Chinese New Village which is a re-settlement site set up during the Communist emergency period of British rule in Malaysia in the mid-1950s. The role of the MCA's political elite has helped to create the New Village Master Plan 2005 which serves as a guide and reference to the Federal Government and the State Government in the
\end{abstract}


development of New Villages. However, limited provisions and unclear policies have resulted in New Villages facing a multitude of problems and have frustrated development in New Villages especially in tandem with the requirements of national development. The residents of New Villages are neglected, and many are experiencing social and economic problems. The paper evaluates these problems with reference to the role of local leaders and development objectives for New Villages in the context of national goals.

Keywords: development, MCA, new villages, political elites

\section{Introduction}

Malaysia is a plural country comprising of three main ethnic groups, namely the Malays, Chinese, Indians and Others thereby making it known as a 'Pluralism Society' (Weiss, 2013). Malaysia practices Parliament democracy with a constitutional monarch since attaining independence in 1957 (Hairany Naffis, 1989). Parliament democracy means the citizens are involved in the state of governance and constitutional monarchy means maintaining the king as the head of the nation.

Malaysia has practiced the multi-party concept in its political system since the first local election in 1955, based on the "first past the post" concept. Malaysia's premier political party, the Barisan Nasional (before 1973 it was called the Alliance Party) consists of three dominant component political parties; the United Malays National Organization (UMNO), MCA (Malaysian Chinese Association) and MIC (Malaysian Indian Congress). The Barisan Nasional has won in all the general elections held thus far and has ruled the country since independence in 1957 (Welsh, 2013). These are ethnic based political parties where the UMNO represents the Malays, the MCA for the Chinese and the MIC for the Indians. As the years passed, other ethnically mixed political parties were admitted as members of the Barisan Nasional such as the Gerakan and some lesser component political parties in Sabah and Sarawak (Welsh, 2013).

Since the New Villages will be the focus of this paper and where the majority of its populace is ethnic Chinese, it is inevitable that the position of MCA and its role in the New Villages comes to the fore. MCA is a Chinese organization formed to represent the interests of the Chinese community (Ho, 2004). MCA is the first political party associated with the New Villages and has played an important role in safeguarding the welfare of the residents and striving for the development of New Villages since its inception. The New Villages is one of the outcomes of the British colonization and inhabited largely by the Chinese (Mohd Zaki, 2003). The settlements had existed since the period of the communist emergency between the years 1948-1960. During this phase of British rule in Malaya and the war against the communist insurgency in the country, the British had gathered the Chinese settlers who were living at the fringes of the jungle into various organized and guarded settlements called New Villages to protect and fend off the communists (O'Ballence, 1966).

Consequently, with the communist threat no longer a problem, the people continued residing in the New Villages and eked out an independent livelihood for themselves; either through agriculture or small businesses which soon grew into the small and medium industries presently. Certainly, there were some villages which were not economically viable that 
resulted in some of its residents relocating to other towns leaving the houses in disrepair and partly abandoned. The desertion of these villages had a negative social and economic impact on the remaining settlers and their settlements (Phang \& Tan, 2014). The existence of New Villages has raised various issues related to national development. Among the major issues are those related to social and economic aspects which are difficult to resolve due to lack of funds and unclear plans for the New Villages. Only in 2005 was a proper New Village Master Plan produced and used as a guide and reference by government agencies and political elites for the development of New Villages. As a result of ad hoc policies for the development of New Villages, many of them were left in limbo but some managed to grow and modernize due to their own resources. Thus far, the growth of the New Villages has been haphazard and not in tandem with the overall development of the nation (Phang \& Tan, 2013). This situation has influenced the residents of New Villages to be particularly focused on political issues and the relationship of their village leaders or the local elites with the MCA. Although various development approaches have been taken by the MCA, the achievement of New Villages in its development objective has remained largely low. The aim of this paper is to study the role of the political elites at the national and local levels in the light of the elite theory and examine the development of New Villages in the process of modernization in Malaysia.

\section{Literature Review}

\subsection{Political Elites}

According to Higley (2008) political elites is a group of individuals, companies, political parties or public organizations that manages the government and all manifestations of political power. According to Lasswell, Lerner and Rothwell (1952) political elites include the group of authorities in the system and the political body of the government of a country. In this theory the instructions are received from the superiors and flow down. In terms of power flow, the higher the position in the hierarchy, the higher the power.

Political elites refer to some individuals who have an important role in a community group (Keller, 1963). The study by Keller grouped the political elites into two groups. The first group is the elites who are single individuals, usually called political elites (Aristotle, Gaetano Mosca, Pareto). Meanwhile, the second group, is a grouping of individuals or elites that share the power, responsibility, and rights or rewards (Saint Simon, Karl Mainnheim, Raymond Aron). This statement is backed by Marvick (1976) who explained that although political elites are often seen as united groups, there are among its members some who often compete and have different interests. The competition and the differences often occur in the struggle for power or elite circulation.

Putnam (1976) states that in general social scientists have divided political elites into three perspectives. First, it is the structural or positioning angle. This view explains that the elite position in the upper layers in the structure of society has led them to play an important role in the community's activities. This position can be achieved through business or social standing, or via descendancy or caste. Second is the institution's point of view. This view is based on an institution that advocates for elites in society. Mills (1956) explains that to gain fame, wealth and power, one must enter into a large institution, because the position the 
person occupies in the institution extends to him the privilege of valuable experiences and to master the knowledge. Third is the perspective of political power. When political power is defined in terms of ability to influence government decisions and activity and the person who has this power can be identified as elite. This view clearly states that political elites have a huge influence in the process of decision making in the government. Political elites are individuals or groups of elites who have influence and power in the process of political decision making (Lasswell et. al, 1952). In Malaysia, political parties that have long dominated the government are Barisan Nasional and its dominant component parties of the UMNO, MCA and the MIC.

Based on the situation of New Villages, whose residents are mainly Chinese, it is obvious that the MCA became the first political party to assume responsibility for maintaining the interests and privileges of the New Villages (Malaysian Chinese Association, 2004). The origins of MCA was initially as a charitable organization but transformed and declared a political party to serve, safeguard the welfare and champion the rights of the Chinese community. This was possible through its association and co-operation with the UMNO party and the MIC. Together, they formed the Alliance Party that has ruled the country since its independence in August 31 1957. As a consequence, this collaboration led to MCA to be identified as the political party representing the Chinese community; the UMNO representing the Malays and the MIC representing the Indian community as stated previously. Subsequently their participation in local elections was very successful and they dominated the government administration at both the federal and state levels. The MCA leaders became more influential and powerful and identified as the political elites of the community both at the national and village levels. For MCA, it gained the confidence of the Chinese community particularly at the New Villages level and it enhanced the position of their leaders at the village level.

Pareto (1915) divided the society into two classes, namely the governing elite and the non-governing elite. In the context of Malaysia the ruling elite is a political elite. For the New Villages at the Federal Government level, the ruling elite comprise of ministers and officers from the Ministry of Housing and Local Government. This Ministry has traditionally been headed by the leader of the MCA and is responsible for local government matters. By virtue of the New Villages having a majority of Chinese residents and the Minister also of Chinese origin, the affairs of the New Villages automatically came under the auspices of this ministry. At the same time, as these villages were located in the various states, the State Governments to a certain extent were responsible for the New Villages. Thus, the MCA elected representatives or Exco members of the State Government were identified as the ruling elite for the New Villages at the state level. Based on Marvick's (1976) opinion, the community leader can be categorized as a political elite and seen as the leader in the context of New Villages in Malaysia. The role, duties and responsibilities of the community leader are comprehensive and full of challenges that cover not only the welfare, health and community matters of the villagers, but also including physical, economic, social, security, religious and cultural aspects.

The political elites in the Federal Government and the State Government have their respective jurisdictions and play an important role in the development of New Village (Lim \& Fong, 2005). The Federal Government through the Ministry of Housing and Local Government 
proposed the setting up of the Village Development and Security Committee (VDSC) and the Federal Village Development and Security Committee (FVDSC) for administering the New Villages and these committees have federal and state leaders or their representatives as members together with appointed villagers also as committee members. In most cases these appointed villagers are members of the MCA and thus can be identified as the political elites at the New Villages. The VDSC and the FVDSC are the grassroots political elites that play an important role in helping residents solve problems in New Villages and represent the residents of New Villages in voicing views or issues at the district level. Apart from that, the VDSC and the FVDSC are the architects and planners for their respective New Villages in the various states. The basic idea is to ensure that the New Villages can be developed in terms of meeting the needs for infrastructure, social and economic projects and strengthening the role and influence of MCA at the grass root level. Indeed, identified as political elites in the New Villages, these leaders have a significant role in ensuring the sustainability of their position as leaders of the community. In this matter, the residents of these villages are made aware of their reliance on these political elites who will ensure that their villages will be able to obtain financial support for the continual growth of their settlements. Thus, during the general elections, these political elites will have to defend their positions within the political party by winning in the elections and many depend on the support and votes cast by the villagers for them. To convince the voters especially in the New Villages, the political elites will promise to bring in new development projects, increase funding allocations, improve services and distribute benefits to the local villagers.

Needless to say, political elites play an important role in maintaining the status quo of their powers and influence; subdue public dissent and ensure satisfaction in the community. But given the changing political scenario at the national level, political dissatisfaction appears to have arisen especially with regards to the effectiveness of the MCA as the voice of the Chinese community. This sentiment seems to have permeated to the New Villages and the role of local elites has been questioned. Village voices raise the issue of the effectiveness of these leaders and their capacity to represent them. While in the past, many of the older residents have been ingrained with the idea that only the political elites in the form of MCA members can decide for them, their children and younger residents do not share this same view. These youths are better educated, more aware of their rights and enlightened with modern technology and the social media. As such, these younger residents tend to pose challenges to the political elites and present their dissenting views in various forms; primarily through the ballot box by casting votes according to their wishes and not to blind loyalty for the existing political elites or leaders of the village community. Indeed, many of the political elites are facing a dilemma; a need to maintain control and power but at the same time trying to appease the local community who are not afraid to question the leaders and also to speak out and express their opinions in matters that are their concern regarding the New Villages.

\subsection{Development of New Villages}

Todaro (1977) argues that development involves the process of reorganizing and reorienting the economic and social system. According to Rahimah (1989) development can be shown by the eradication of poverty, decreasing unemployment and closing the inequality gap. 
The fast-paced development and transformation over the last decade not only successfully changed the growth and development of the country but also affected the country's socio-economic environment, including the growth of New Villages. Based on the situation of the New Villages, development refers to the overall economic and social development of the new village, involving basic facilities and services such as transportation and communication facilities, electricity supply and infrastructure growth and development. The development of New Villages can be traced from since the country achieved its independence in 1957 together with the important roles of the Federal and the State Governments (Lim \& Fong, 2005).

According to Lim and Fong (2005), at the Federal Government level, New Villages was designated as the responsibility of the Ministry of Housing and Local Government and placed under its portfolio starting in 1974. There was a short period from 1986 to 1988, when the functions of New Villages came under the auspices of the Ministry of National and Rural Development. Then from 1988 until 2014 the New Villages was the responsibility of the Ministry of Housing and Local Government (later renamed Ministry of Urban Wellbeing, Housing and Local Government). However, when this Ministry was placed under a Minister from UMNO, the administration of New Villages once again moved from the Ministry of Housing and Local Government to the Prime Minister's Office to be placed under a Chinese Minister in the New Village Division. Probably, the reason is that the Ministry of Housing and Local Government is now under a Minister not of Chinese ethnicity. As the majority of residents in New Villages are mainly Chinese, it is seems appropriate that a Chinese Minister is appointed to be responsible for the New Villages. Table 1 provides information regarding the administration of New Village at the Federal Government level.

Table 1. Administration of New Village at the Federal Government level

\begin{tabular}{ll}
\hline Year & \multicolumn{1}{c}{ Ministry } \\
\hline $1972-1974$ & Ministry with Special Function in the Prime Minister Department \\
$1974-1975$ & Ministry of Housing, Local Government and New Village \\
$1975-1986$ & Ministry of Housing, Local Government and Village Development \\
$1986-1988$ & Ministry of National and Rural Development \\
$1988-2014$ & Ministry of Housing and Local Government \\
$2014-$ current & New Village Division, Prime Minister Department \\
\hline
\end{tabular}

Source: The New Villages in Malaysia (2005)

Since independence, growth and development of Malaysia has been on a trajectory path and the standard of living of its people had improved. Overall, the threat from the communist insurgency had been quelled and national security had improved. This process was happening at the national level with the Barisan Nasional and its component multi-ethnic parties experiencing popularity among the voters. The security situation at the New Villages experienced a similar improvement and to a certain degree calmed the residents and heightened the image of the local elites and MCA leaders. Most of the residents of New Village were allowed to undertake various economic activities independently although the emergency order was only abolished in July 1960 (Lim \& Soong, 2002). But it seemed that this effort did not translate into higher productivity and better opportunities for the village community or at least in tandem with national growth. It can be argued that this was 
happening due to various constraints hampering the growth and development of the New Villages. Foremost is the issue of lack of finance for infrastructure projects, followed by a feeling of marginalization by the residents, migration of youths to the cities and towns and basically being ignored by the local elites in the decision making process.

According to An Overall Analysis of their Socioeconomic Development Trend and Problems, 1986 (Malaysian People's Movement Party, 1986), the Local Council Ordinance 1952 had empowered the district offices to administer and develop areas in New Villages but during this period, the district offices were experiencing financial constraints themselves. Needless to say, this financial inadequacy and limited funding allocation affected the development of New Villages.

The lack of development, weak infrastructure and the absence of maintenance work in the New Villages gave rise to various social problems that affected the harmony of the community (Ho, 2004). Historical data indicate that, in the early 1970s, the economic and social problems that occurred worsened as the growth in New Villages was slower compared to the rapid development taking place at the national level. Indeed, this feeling of being abandoned and marginalized ultimately led to dissatisfaction among the village community (Malaysian People's Movement Party, 1986). Such inequality in development and disparity cannot be allowed to deteriorate further as they will have dire political consequences for the ruling political party at the national level. Thus, this matter came to the attention of the then second Prime Minister of Malaysia in 1972 when he directed the implementation of the development of the New Villages or known as Kampung Baru as part of the country's main growth process for national uniformity. This led to a change in administration of New Villages. When once it was directly under the state district office, the New Villages became a local government responsibility. This meant that the New Villages would then be administered and supervised by the district councils with leadership from the Minister in the Ministry of Housing and Local Government at the federal level. It signified the seriousness of the Federal Government for the affairs of the New Villages. This attention should result in provision of more resources and increased allocation for the New Villages and hopefully would lessen the dissatisfaction and frustrations of the villagers.

Preliminary findings in the report established that at least one third of the Chinese population in Malaysia is located in the New Villages (New Villages Master Plan Report 2005). It also said that in general the development pace of the New Villages was not in tandem with the overall growth of the nation. As such the report suggested that for nation building it is only appropriate that due recognition be given to the New Villages and to bring them into the mainstream national development process.

With regards to the study of the New Villages in Malaysia, the elite theory is used to analyze the decision making process and political power interaction between the different categories of leaders at the local and national levels. Referring to the situation of New Villages, many policies are decided based on the dynamics of politics that occur between the village or local elites and national elites. At the same time, the impact of globalization, social media and e-technology have influenced the villagers and their mind-set. As a result, the villagers have 
begun to compare their settlements with the rest of the nation and to question their rights and relationship with their leaders. The discussion follows on the elite theory and the impact of modernization on a village community.

\section{Methodology}

This study uses a qualitative approach that explores the experiences of respondents who are directly involved with New Villages (Robson, 2011). This is supplemented by the narrative procedure (Chase, 2005) in reviewing the expressed experiences and challenges lived by the individual respondent (Polkinghorne, 1995). In analyzing the data from the interviews, the description of events and happenings were then configured into key elements and adopted for discussion and findings.

The following questions were posed to the respondents:

Q1. What is the role of political local elites in New Villages?

Q2. How does modernization enable the residents to express themselves?

Q3. What are the challenges faced by the New Villages in trying to develop and not be left out from the national development plan?

In order to answer these questions, a survey was carried out to select the appropriate respondents. The respondents consist of fifty seven (57) people of which three (3) are Ministers, two (2) are Village Directors, seven (7) are Village Development Officers and forty five (45) are Community Leaders. According to Fraenkel and Wallen (2007), the sampling process for this study is purposive sampling and is in accordance with the requirements of qualitative studies. The respondents were selected based on their knowledge and experience in the administration of the New Villages. Data from the interviews was transcribed and transferred to the data storage to ensure security. The data was analyzed using thematic analysis. Secondary data was used to gather information on resource allocation and infrastructure on New Villages. Data from the Malaysia Development Plan documents was also used for this study.

\section{Findings}

The study found that the MCA's political elite and component party elites have played an important role in safeguarding the welfare of the New Villages and striving for their development. Interviews were carried out with key persons linked with the New Villages such as previous Ministers of the Ministry for Housing and Local Government, Officers from the New Village Division and the Village Development Officers found that political elites influence the development of New Villages. The respondents were also of the view that the MCA has a major role in helping the progress of development in the New Villages.

Former Minister in the Ministry of Housing and Local Government and presently a Minister with the Prime Minister's Office stated that:

"Although I am from UMNO I was entrusted with looking after the New Villages when I became the Local Government Minister. However, the MCA still continued to assist and 
extend its support to my Ministry in implementing development projects in the New Villages; all in the interest of the residents of the New Villages".

(Minister 1, 2017)

The MCA leaders and the previous MCA Minister in the Ministry of Housing and Local Government have always strived for the development of New Villages. The results from the interviews with the Village Development Officers agree that the MCA political elites play an important role in the development of New Villages.

A Village Development Officer stated that:

"The development of New Villages without MCA has no future. Under the MCA President, the residents of New Villages can enjoy the facilities provided by the government. This is because the MCA is working hard to upgrade the living standard of New Villages"

(Officer 1, 2017)

In the early days, MCA was established as a charitable body but has since been transformed into a political party fully committed to safeguarding the welfare of ethnic Chinese. MCA's political leaders have successfully fought for infrastructural projects to help the New Villages and worked well with the national government to bring development and benefits to improve the lives of the villagers.

Former Minister in the Ministry of Housing and Local Government stated that:

"After being appointed as the Minister of Housing and Local Government from 1999 the government allocation for the New Villages was increased through the Ministry's own initiative. Upon approval from Prime Minister's Office, a special provision for the preparation of a new village master plan was approved. At that time the New Villages' needs had to be given consideration and certain policies had to be decided for not only infrastructure or environment, but also social, cultural and other aspects".

(Minister 2, 2017)

In 2005, the New Village Master Plan was accepted by the government due to the good working relationship of MCA's political elite with the government. The New Village Master Plan is a guideline for the development of New Villages to become a productive and developed community. As such the development plan for the New Villages appeared more systematic and balanced with support from the national government. The strategy was to bring the New Village development in parallel with the current direction of national development.

Minister in the Prime Minister's Office stated:

"Chinese New Villages have never been neglected either in terms of basic infrastructure or more comprehensive development since their establishment in the country and under the Barisan Nasional government. The MCA Party as a Barisan Nasional Component Party has helped to realize the progress of the Chinese New Villages around the country". 
(Minister 3, 2017)

The existence of the New Village Master Plan is one of the efforts of MCA and its role in the development of New Villages. After the establishment of this master plan, programs such as the New Village Development Program, Home Improvement Program and New Village Special Loan Scheme Program were introduced, and their policies outlined in the master plan. These programs have brought many benefits to the residents of New Villages in terms of improving their quality of life.

Former Minister in the Ministry of Housing and Local Government stated that:

"After the New Village Master Plan, funding continued to be given to the New Villages in the form of several development programs of which the most significant one is the Village Development Program. The Village Development Program has two specific objectives of making New Villages a place of human settlement and ensuring a better quality of life via the provision of infrastructure and social facilities and integrating New Villages into the overall urban and rural development plans"

(Minister 2, 2017)

In enabling further growth of the New Villages, beginning from the Second Malaysia Plan (1971-1975), the New Villages were recognized as a part of the mainstream of national development and allocated RM12 million for development (Table 2). Included were a number of other provisions that were given for them to develop according to national growth trend. Subsequently, under the various Malaysia Plans, the New Villages were allocated funding for infrastructure and development projects.

Table 2. Financial Provision for New Village Development

\begin{tabular}{lcc}
\hline \multicolumn{1}{c}{ Malaysia Plan } & Year & Allocation \\
\hline First Malaysia Plan & $1966-1970$ & - \\
Second Malaysia Plan & $1971-1975$ & RM 12,000,000 \\
Third Malaysia Plan & $1976-1980$ & RM 19,000,000 \\
Fourth Malaysia Plan & $1981-1985$ & RM 25,000,000 \\
Fifth Malaysia Plan & $1986-1990$ & RM 13,000,000 \\
Sixth Malaysia Plan & $1991-1995$ & RM 21,000,000 \\
Seventh Malaysia Plan & $1996-2000$ & RM 33,000,000 \\
Eighth Malaysia Plan & $2001-2005$ & RM 124,600,000 \\
Ninth Malaysia Plan & $2006-2010$ & RM 293,500,000 \\
Tenth Malaysia Plan & $2011-2015$ & RM 274,100,000 \\
Eleventh Malaysia Plan & $2016-2020$ & RM60,517,188 \\
& & (until 2016 only) \\
\hline
\end{tabular}

Source: Tabulated from the Malaysia Plans

The fundamental issue arising from these allocations to the New Villages confirms the powers of the ruling elites on local and national politics. The funding process ultimately enhanced the image of the local elites as they are directly linked to the MCA political party which is one of the main component party of the ruling Barisan Nasional. It also shows that MCA's political link with the UMNO whose leader is the Prime Minister has benefitted the local elites and their position at the village level. Overall, this recognition of New Villages 
and bringing them into mainstream development also serve to enhance the powers of the political elites at the national level and strengthen their political power base. At the same time a special unit, the New Village Division was set up in the Prime Minister's Department to initiate and resolve any problems arising in the New Villages. This Division has a dual role of coordinating activities at the local level with the national level as well as administering development projects and funding for the New Villages.

However, as findings indicate, many of these development programs for the New Villages were mainly ad hoc and there were no official policies for New Villages at the national level. It was only with the appointment of the MCA leader Ong Ka Ting as the Minister of Housing and Local Government at the end of 1999, that he commissioned a detailed study of the problems and weaknesses of New Villages in Malaysia. Even with financial grants allocated to the New Villages there were still gaps in development and the New Villages were finding it hard to "catch up" with the rest of the country. With dissatisfaction increasing again within the community of the New Villages, the MCA Minister established a special division within the Ministry to oversee the problems and requirements of the New Villages. Investigations started in 2004 and the output was a master plan report for the New Villages, i.e. New Villages Master Plan Report 2005. This comprehensive report outlined the strength and weaknesses of the New Villages and provided various short and long-term development strategies for New Villages that were implemented in 2005 (Lim \& Fong, 2005).

\section{Conclusion and Suggestions}

This study is based on examining the role of political elites and effects of modernization in the development of New Villages in Malaysia. The findings of the study have attempted to discuss and answer the research questions and issues raised in this paper. It is inevitable that the development of New Villages will face the challenge of modernization brought on by the process of globalization. Modernization and social media had made the residents in the New Villages more aware of the condition of their villages and they want to be given the same development opportunities to grow with the rest of the nation. At the same time, the government has to continue giving financial aids for development projects to ensure that there are economic activities for the residents to continue working and living in the villages. This is to discourage them from moving out of the villages but to live and contribute to the growth of the New Villages. This is because a strong New Village can be an asset to the country's economic growth. There are plans by the government to develop several other New Villages that have been identified with economic and business potentials. Consequently, this will place them at par with the towns and cities and assimilate them with the surrounding areas.

In so far as the process of politics is concerned, it is shown that political linkages are important for continual support for the New Villages. The influence from national politics has helped the local elites to further entrench their local power base and extend their influence in the decision-making process of the New Villages. As long as the MCA is a component party of the ruling Barisan Nasional, and the villagers are still maintaining their support for the leaders, it can be assumed that financial support will continue from the Federal Government 
for the development of the New Villages. It cannot be denied that the role of MCA and the local elites have contributed to the success of several development projects for the New Villages thus far. This study has contributed to the theory that political elites are significant to growth and development of villages that are not within the mainstream and focus of national policies.

Much still needs to be done for the development and growth of the New Villages. There is a necessity for an official national policy to guide the development of the New Villages and address the social and economic issues besetting many of the settlements; foremost, the problem of integrating the New Villages into the mainstream of national development. Further detailed study of these challenges should be carried out to ensure that right decisions and policies are made for the New Villages and that the Malaysian government's aspiration in achieving a developed status will be a success.

\section{References}

Chase, S. E. (2005). Narrative Inquiry: Multiple lenses, approaches and voices. In NK Denzin \& YS Lincoln (Eds) The Sage Handbook of Qualitative Research (3rd Edition) pp. 651-679. Thousand Oaks, CA: Sage Publications.

Fraenkel, J. R., \& Wallen, N. E. (2007). How to design and evaluate research in education. New York: McGraw-Hill.

Hairany, N. (1989). Pendapat umum dalam pembentukan dasar dan perkembangan politik di Malaysia: Satu renungan. Jurnal komunikasi, 5, 7-14.

Higley, J. (2008). Elite theory in political sociology, University of Texas at Austin.

Ho, H. L. (2004). Darurat 1948-1960: Keadaan sosial di Tanah Melayu. Kuala Lumpur: Penerbit Universiti Malaya.

Keller, S. (1963). Beyond the ruling class. Strategic elites in modern society. New York: Random House.

Lasswell, H. D., Lerner, D., \& Rothwell, C. E. (1952). The comparative study of elites: An introduction and bibliography. Stanford, CA: Hoover Institution.

Lim, H. F., \& Fong, T. Y. (2005). The new villages in Malaysia: The journey ahead. Kuala Lumpur: Institute of Strategic Analysis and Policy Research.

Lim, H. F., \& Soong, W. Y. (2002). Malaysian Chinese new villages after 50 years. (2nd ed.). Centre for Malaysian Chinese Studies. (In Chinese).

Malaysian People's Movement Party. (1986). New villages in Peninsular Malaysia: An overall analysis of their socioeconomic development trend and problems. Kuala Lumpur: Parti Gerakan Rakyat Malaysia.

Marvick, D. (1976). Continuities in recruitment research: Towards a new model, in elite recruitment in democratic politics. In Eulau and Czudnowski, (Ed.), Elite recruitment in democratic politics: Comparative studies across nations. New York: Jon Wiley. 
Mills, C. W. (1956). The power elite. New York: Oxford University Press.

Mohd, Z. M. S. (2003). Propaganda dalam darurat pertama di Malaysia, 1948-1960. Kuala Lumpur: Penerbit Universiti Malaya.

New Villages Master Plan Report 2005. Ministry of Housing and Local Government. Kuala Lumpur.

O’Ballance, E. (1966). Malaya: The communist insurgent war, 1948-1960. London: Faber.

Pareto, V. (1915). The mind and society: A treatise on general sociology. New York: Dover.

Phang, S. N., \& Tan, T. H. (2013). New villages in Malaysia: Living conditions and political trends. Malaysian Journal of Chinese Studies, 2, 17 - 27.

Phang, S. N., \& Tan, T. H. (2014). Re-positioning urban-based new villages in Malaysia towards sustainable living and a better quality of life. Journal of Governance \& Development, $10,141-167$.

Polkinghorne, D. E. (1995). Narrative configuration in qualitative analysis, Qualitative Studies in Education, 8(1), 5-23. https://doi.org/10.1080/0951839950080103

Putnam, R. D. (1976). The comparative study of political elites. Englewood Cliffs, NJ: Prentice-Hall.

Rahimah, A. A. (1989). Pengantar sosiologi pembangunan. Kuala Lumpur: Dewan Bahasa dan Pustaka.

Robson, C. (2011). Real world research: A resource for social-scientists and practitionerresearchers (3rd ed.). Oxford: Blackwell Publishing.

Todaro, M. P. (1977). Economic development in the third world: An introduction to problems and policies in a global perspective. New York: Longman.

Weiss, M. L. (2013). Malaysia's 13th general elections: Same result, different outcome. Asian Survey. 53, 1135-58. https://doi.org/10.1525/as.2013.53.6.1135

Welsh, B. (2013). Malaysian elections 2013: A step backward. Journal of Democracy, 23(4), 136 - 150. https://doi.org/10.1353/jod.2013.0066

\section{Copyright Disclaimer}

Copyright for this article is retained by the author(s), with first publication rights granted to the journal.

This is an open-access article distributed under the terms and conditions of the Creative Commons Attribution license (http://creativecommons.org/licenses/by/4.0/). 